\title{
Testování sorpčních filtrů na bázi granulovaného aktivního uhlí pro účely dočištování pitné vody
}

\section{TOMÁŠ MIČANÍK, JIŘí OCEÁNSKÝ, JIŘí LISNÍK, TOMÁŠ OCELKA}

Klíčová slova: sorpce - desorpce - katalytická destrukce - dehalogenizační jednotka granulované aktivní uhlí - pesticidy - vodní nádrž Švihov - regenerace sorpčních náplní

\section{SOUHRN}

Tento př́spěvek se věnuje výzkumu účinnosti sorpce a odstranění organických látek, zejména pesticidních z exponovaných sorpčních náplní na bázi granulovaného aktivního uhlí (GAU). Představuje modelové testy účinnosti pěti různých typů GAU. Výsledky mohou přispět k posouzení vhodnosti filtračních náplní pro realizovaný investiční záměr GAU filtrace, objektu, který bude sloužit k dočištování upravené vody na úpravně vody Želivka. Testy sorpční účinnosti probíhaly $v$ kolonovém uspořádání pro 15 významných polárních látek, jejichž výskyt v povodí Želivky a ve vodní nádrži Švihov byl potvrzen. Byla zjištěna vysoká sorpční účinnost presahující 99 \% pro většinu testovaných látek. Součástí řešení bylo ověření možnosti využití technologie katalytické destrukce CDC (Catalytic Destruction using Copper) pro regeneraci (reaktivaci) sorpčních náplní. Destrukční účinnost technologií CDC byla zkoumána v laboratorním reaktoru, pro většinu látek bylo taktéž dosaženo vysokých hodnot jejich eliminace nad $99 \%$.

\section{ÚVOD}

Tento článek představuje výsledky řešení projektu Čistá voda - zdravé město, Konceptu I: „Studie vnosu pesticidů do vodárenské nádrže Švihov (Želivka) s využitím nových vzorkovacích technik a odstranění organických látek ze sorpčních filtrů za ozonizací vysoce-účinnou chemickou destrukcí" se zaměřením na výsledky testování několika druhů sorpčních náplní pro záchyt polárních organických látek z vodního prostředí.

Povodí vodárenské nádrže Švihov, největší v České republice, je charakteristické prítomností lidských sídel a zemědělským využíváním krajiny. Antropogenní vliv na povrchové vody je monitorován a vyhodnocován správcem povodí (Povodí Vltavy, s. p.) [1, 2]. Rovněž v rámci řešení projektu Čistá voda - zdravé město byly pomocí pasivních vzorkovacích technik na prítocích do VN Švihov a na ÚV Želivka detekovány organické látky nepolárního i polárního charakteru s převahou účinných látek rostlinolékařských př́pravků [3]. Pro efektivní odstranění zbytkových organických látek z upravené pitné vody je v areálu Úv Želivka uskutečňována rozsáhlá investice dalšího stupně čištění filtrace pomocí granulovaného aktivního uhlí (GAU) [4], kde bude upravená voda za ozonizací dočištována pomocí tlakové filtrace. Za tímto účelem vyrobené speciální GAU je při výrobě upraveno takovým způsobem, aby ve zvýšené míře adsorbovalo polární látky. Filtrace pomocí GAU technologie pro úpravu pitné vody za účelem odstranění polárních kontaminantů je komerčně dostupná s tím, že vyžaduje účinnou regeneraci (použivá se též pojem reaktivace) filtrační náplně $[5,6]$. Výběr filtrační náplně je též významný z ekonomicko-provozního hlediska. Za účelem zjištění jejich sorpčních schopností je v areálu úpravny již několik let v provozu aparatura sorpčních kolon s několika typy GAU, na které je vedena upravená voda za ozonizací. V rámci projektu Čistá voda - zdravé město byly testy sorpce a desorpce sorpčních náplní realizovány s vysoce kontaminovanou vstupní vodou, aby tak bylo možné v kratším časovém úseku (než několika let) porovnat vhodnost jednotlivých typů sorpčních náplní, jejichž použití v objektu GAU filtrace připadá v úvahu.

Za tímto účelem byly provedeny modelové testy pěti typů sorpčních náplní na bázi GAU. Výsledky mohou přispět k rozšírení znalostí o jejich vlastnostech a možnosti využití technologie CDC pro regeneraci náplní. Článek zhodnocuje:

1. testy sorpce vybraných organických látek (zejména pesticidů) za účelem zjištění sorpční účinnosti,

2. destrukční testy z exponovaných sorpčních náplní katalytickou destrukcí pro zjištění účinnosti desorpce.

\section{METODY}

\section{Testy sorpce}

Modelové sorpční testy byly uskutečněny pomocí aparatury sorpčních kolon jako vhodného prostředku pro výzkum sorpčních a desorpčních procesů vybraných organických látek na zvolených typech aktivního uhlí. Sorpční aparatura byla umístěna $v$ technologické hale $s$ relativně nízkou teplotou $v$ porovnání s teplotou laboratorní (teplota vody nepresáhla $+15^{\circ} \mathrm{C}$ ).

Sorpční kolony pro filtraci pomocí aktivního uhlí jsou tvořeny dvěma nádobami, první pracovní a druhou kontrolní, která indikuje ztrátu filtrační schopnosti první kolony. Ta může být způsobena rychlým průchodem média přes kolonu a/nebo plným nasycením sorpční náplně. Technická specifikace aparatury:

— maximální filtrační průtok: $2 \mathrm{~m}^{3} \cdot \mathrm{h}^{-1}$,

— rychlost vody při filtraci: $11 \mathrm{~m} \cdot \mathrm{h}^{-1}$,

— doba kontaktu s aktivním uhlím: 5 min 40 s, 
— prázdný prostor v nádobě: $25 \%$,

— velikost jedné nádoby: průměr 490 mm, výška 2130 mm,

— objem jedné nádoby: 260 I,

— objem vyhrazený pro materiál v jedné nádobě: 190 I,

- tlakový režim kolon: přetlak.

(Pozn. Informace od výrobce vycházejí z údajů pro jím dodávané aktivní uhlí CG 900.)

Kolony byly testovány v sériovém zapojení, vodní médium do kolony vstupovalo ze vstupní nádoby a po filtraci přecházelo do výstupní nádoby. Během předběžných testů byly odebírány vzorky GAU ze spodní části první kolony, aby byla zjištěna případná kontaminace celého objemu kolony a z toho vyplývající ztráta filtrační schopnosti. Výsledky počátečních testů byly negativní, proto byla při porovnávacích testech využívána pouze jedna kolona.

Experiment se skládal ze tři provozních režimů:

1. promíchání - cirkulace vody s definovanou koncentrací vybraných rostlinolékařských prípravků ve vstupní nádobě,

2. purifikace - vlastní filtrace "kontaminované" vody, proces průchodu vodního média ze vstupní nádoby do kolon, dále do výstupní nádoby a jeho přečerpání zpět do vstupní nádoby k prípravě pro prípadnou další filtraci je označován jako jeden pracovní cyklus, optimalizace počtu pracovních cyklů byla součástí počátečních experimentů,

3. průplach - dekontaminace kolon a celé aparatury čistou vodou.

Schematické znázornění zapojení aparatury a její fotografie zobrazují obr. 1 a 2.

Pverese

Masi

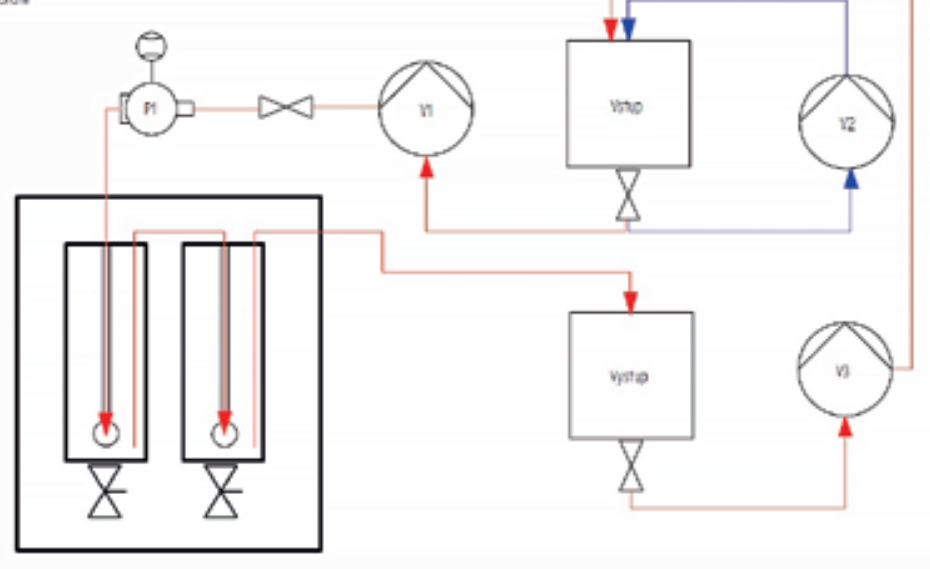

Obr. 1. Schéma zapojení kolonových testů

Fig. 1. Columns tests diagram

Legenda: Vstup - vstupní nádoba o objemu 1 m³, Výstup - výstupní nádoba o objemu 1 m³, P1 - odstředivé čerpadlo, V1 až V3 - cirkulační čerpadla

Počáteční optimalizační testy byly provedeny na uhlí Filtrasorb TL830 (dále označeném jako GAU1). Je možné je shrnout do těchto bodů:

1. Optimalizace analytické metodiky LC-MS pro skupinu polárních organických látek, měření standardních referenčních materiálů daných látek a komerčních směsí, kde se zkoumal matriční efekt. Použitá analytická technika: LC-MS systém, typ TSQ Quantum Access, Thermo Electron Corporation.
2. Výběr zkoumaných látek, který vycházel ze seznamu polárních organických látek (pesticidů) nalezených v povrchové vodě nebo surové vodě na VN Švihov a nejběžněji použivaných pesticidů dostupných $v$ komerčně používaných směsích.

3. Příprava vodného roztoku rostlinolékařských prípravků o definované počáteční koncentraci účinných látek. Počáteční objem roztoku ve vstupní nádobě byl vždy 500 litrů.

4. Naplnění kolony zvoleným druhem sorbentu v množství 25 kg.

5. Optimalizace počtu filtračních cyklů na čty̌̌i.

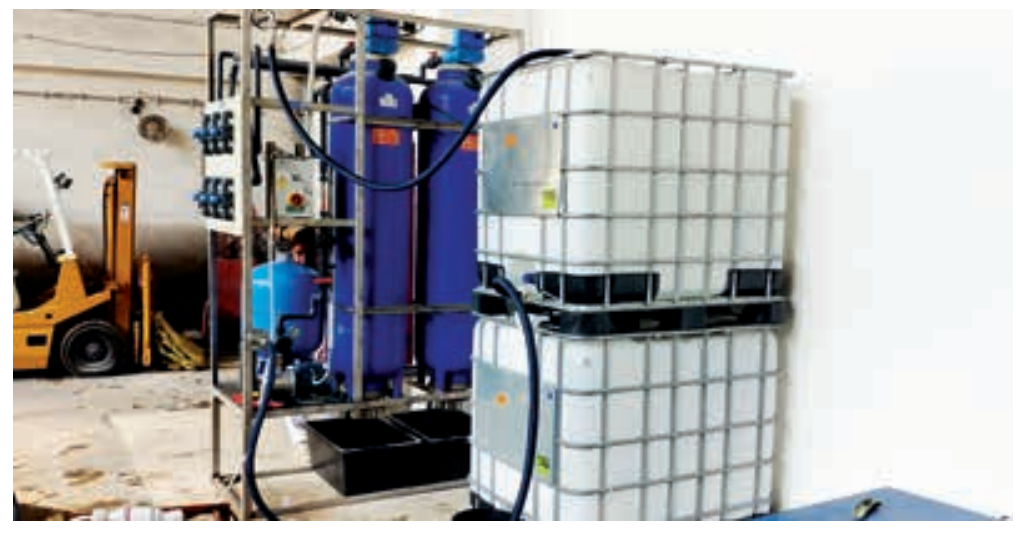

Obr. 2. Kolonová aparatura

Fig. 2. Column tests setup

Po provedení prvotních optimalizačních testů na sorbentu GAU1 byly následně realizovány porovnávací kolonové testy pro pět vybraných typů aktivního uhlí GAU1 až GAU5.

Typy speciálního granulovaného aktivního uhlí byly vybírány podle schopnosti sorbovat perzistentní a polární organické látky, včetně pesticidů, z vody. Výběr byl proveden s ohledem na možné použití v objektu GAU filtrace na ÚV Želivka [4] a z literatury, kde testy na filtraci polárních látek probíhaly nejčastěji právě na GAU od námi vybraných světových výrobců, viz např. [7, 8]. Vybrané typy GAU, vhodné pro úpravu, se liši ve velikosti zrn, způsobu výroby a ostatních parametrech. Seznam druhů aktivního uhlí k testování sorpce a desorpce je uveden $v$ tabulce 1 .

$\checkmark$ tabulce 2 jsou uvedeny vybrané parametry výše uvedených druhů GAU publikované výrobci nebo dovozci. Z ekonomického hlediska jsme získali zkušenost z maloobchodní dodávky 100 kg GAU, kdy cenový rozptyl těchto pěti druhů GAU byl značný (od 78 do 209 Kč/kg bez DPH). V prípadě využití na úpravnách vody je nutno kalkulovat taktéž s cenou za dopravu, množstevní slevou

Tabulka 1. Vybrané druhy filtračnich náplni

Table 1. GAU filters types

\begin{tabular}{|c|c|c|}
\hline Druh GAU & Označení & Výrobce \\
\hline Chemviron Filtrasorb TL830 & GAU1 & \multirow{2}{*}{ Chemviron, Feluy, Belgie } \\
\hline Chemviron Filtrasorb 400 & GAU2 & \\
\hline NORIT GAC 1240 W & GAU3 & \multirow{2}{*}{$\begin{array}{l}\text { Cabot Norit Nederland B. V., } \\
\text { Nizozemí }\end{array}$} \\
\hline NORIT® GAC 1020 EN & GAU4 & \\
\hline AquaSorb 6300 & GAU5 & $\begin{array}{l}\text { Jacobi Carbons Group, } \\
\text { Švédsko }\end{array}$ \\
\hline
\end{tabular}


a zohlednit i další podmínky dodavatelů. Ekonomická rentabilita při výběru je také ovlivněna schopností daných GAU opakované regenerace, tzv. recyklační účinnost a ztrátě materiálu při regeneraci. V literatuře týkající se termické reaktivace [9] se uvádí, že vlivem oxidace a odírání materiálu dochází během regenerace $\mathrm{k} 5$ až $15 \%$ ztrátě materiálu $[7,10]$. Při testech GAU Filtrasorb s opakovanou termickou regenerací [5] byl učiněn závěr, že sorpční schopnosti opakovaně destruovaných vzorkủ byly prakticky stejné. V tomto článku prezentovaná regenerační metoda $\mathrm{CDC}$, kdy se teplota materiálu pohybuje kolem $300^{\circ} \mathrm{C}$, by měla být šetrnější, a tudíž ještě vhodnější pro opakovanou regeneraci.

Při výběru pesticidů byly zohledněny $v$ minulosti naměřené koncentrace reálně se vyskytujících pesticidních látek $v$ povrchové vodě na prítocích do VN Švihov, v surové (neupravené) vodě a v upravené pitné vodě z ÚV Želivka např. [1, 11]. Taktéž bylo přihliženo k výsledkům zjištěným pasivním vzorkováním voda - zdravé město [3] a ke spotřebě účinných látek rostlinolékařských přípravků evidovaných ÚKZÚZ v okresech v povodí Želivky. Mezi kontaminanty ve VN Švihov byly zjištěny i polární nepesticidní látky, zejména benzotriazol (antikorozní složka komerčních a průmyslových přípravků) a DEET (součást repelentů), proto jsme je také přiřadili do našeho seznamu. Celkem bylo vybráno 15 zkoumaných polárních látek, které jsou uvedeny v tabulce 3 společně s navážkou prípravku homogenizovaném v 500 I vody a z toho vyplývající vstupní koncentrace účinné látky $v$ testovacím vodném roztoku. Koncentrace účinných látek byla značně vyšší než reálné dosahované hodnoty koncentrací v surové vodě vstupující do úv Želivka.

Během každého realizovaného filtračního cyklu byly odebrány a následně analyzovány jak vzorky roztoku (kontaminované vody), tak vzorky aktivního uhlí následovně:

1. Vzorky kontaminované vody - odběr byl proveden ze vzorkovací výpustě výstupní nádoby, a to před filtrací po promíchání roztoku a po každé ze čtyř filtrací.

2. Vzorky aktivního uhlí - GAU byly odebírány ze spodní části kolony. Z konstrukce samotných kolon vyplývá omezení, že nelze jednoduše provádět prưřezovou analýzu úbytku pesticidních látek v jednotlivých vrstvách kolony. Odebrané vzorky GAU byly využity pro následné desorpční testy. vody na prítocích do VN Švihov a na úpravnu vody v rámci řešení projektu Čistá

Tabulka 3. Použité prípravky a koncentrace účinných látek ve vstupním médiu pro test sorpce

Table 3. Pesticides agents and active substances concentrations in sorption test input medium

\begin{tabular}{llll}
\multirow{2}{*}{ Př́pravek } & Účinná & Hmotnost & $\begin{array}{l}\text { Koncentrace } \\
\text { účinné látky }\end{array}$ \\
& látka & př́pravku & protest \\
& & {$\left[\mathrm{g} \cdot \mathrm{m}^{-3}\right.$ vod. O] } & sorpce $\left[\mathrm{mg} . \mathrm{I}^{-1}\right]$
\end{tabular}

\begin{tabular}{llll}
\hline Afalon & Linuron & 3,6 & 1,6 \\
\hline Lumax & Terbuthylazin & 5,0 & 0,13 \\
\hline Butisan & Metazachlor & 1,8 & 0,50 \\
\hline DEET & DEET & 1,0 & 0,15 \\
\hline
\end{tabular}

\begin{tabular}{llll}
\hline Benzotriazol & Benzotriazol & 5,0 & 5,0 \\
\hline Chloridan & Chloridazon & 4,6 & 2,3 \\
\hline Infinito & Propamocarb & 0,6 & 0,28 \\
\hline Pirimor & Pirimicarb & 0,6 & 0,30
\end{tabular}

\begin{tabular}{llll}
\hline Ortiva & Azoxystrobin & 1,4 & 0,74 \\
\hline Bandur & Aclonifen & 6,0 & 3,4 \\
\hline Bofix & MCPA & 20 & 4,4 \\
\hline
\end{tabular}

\begin{tabular}{llll}
\hline Revus TOP & Difenoconazol & 10 & 5,7 \\
\hline $\begin{array}{l}\text { Touchdown } \\
\text { Quattro }\end{array}$ & Glyfosát & 50 & 18 \\
\hline Command & Clomazon & 1,8 & 0,51 \\
\hline Bofix & Fluroxypyr & 20 & 1,1
\end{tabular}

Tabulka 2. Vybrané základní vlastnosti jednotlivých filtračních náplní

Table 2. Selected basic characteristics of GAU filters

\begin{tabular}{|c|c|c|c|c|c|}
\hline & GAU1 & GAU2 & GAU3 & GAU4 & GAU5 \\
\hline Měrná hmotnost („,bed“ density) [kg.m-3] & 450 & 450 & 420 & 480 & 380 \\
\hline Specifický povrch (BET) $\left[\mathrm{m}^{2} \cdot \mathrm{g}^{-1}\right]$ & 1000 & 1050 & 1100 & 1150 & 1000 \\
\hline Methylenová modř [mg.g-1], min. & 260 & 300 & 200 & 200 & $250\left(\mathrm{ml} \cdot \mathrm{g}^{-1}\right)$ \\
\hline Jodové číslo [mg/g], min. & 1000 & 1000 & 950 & 1000 & 970 \\
\hline VIhkost (v dopravním obale) [\%], max. & 2 & 2 & 5 & 2 & 5 \\
\hline Tvrdost, min. & 95 & neuvedeno & 97 & 97 & 90 \\
\hline Velikost částic [mesh] & $10 \times 20$ & $12 \times 40$ & $12 \times 40$ & \multirow{5}{*}{$\begin{array}{l}\text { ve formě } \\
\text { peletek } \\
\varnothing \text { cca } 3 \text { mm }\end{array}$} & $12 \times 30$ \\
\hline Koeficient stejnoměrnosti & 1,4 & 1,7 & 1,7 & & 1,7 \\
\hline Střední velikost částic [mm] & 1,4 & 1,0 & 1,0 & & 0,6 \\
\hline Frakce [\%] - ne více než [mm] & $4<0,85$ & $4<0,425$ & $5<0,425$ & & $4<0,316$ \\
\hline Frakce [\%] - ne více než [mm] & $5>2,0$ & $5>1,7$ & $5>1,7$ & & $5>1,7$ \\
\hline
\end{tabular}




\section{TESTY DESORPCE}

\section{Technologie katalytické destrukce CDC}

Prispěvovatel se dlouhodobě zabývá nespalovací destrukcí perzistentních organických látek (POP) v různých matricích. Jedná se zejména o vývoj optimalizované technologie dehalogenace (detoxikace) pevného odpadu [12] obsahujícího vysoce chlorované POPs založené na metodě CDC (Catalytic Destruction using Copper) [13-15]. Principem metody je odtržení radikálu chloru ze skeletu molekuly a jeho převedení na chloridy za teploty kolem $300{ }^{\circ} \mathrm{C}$. Vhodné aplikace pro tuto technologii jsou:

- odprašky a popílky z metalurgického průmyslu (Třinecké železárny, a. s.),

- kontaminované sedimenty z Labe (pesticidní látky),

- regenerace exponovaného aktivního uhlí na úpravně pitné vody.

Technologie CDC je chráněna patentem EU číslo PCT/CZ2004/000024 [16], předmětem českého patentu je použití pro nepolární organické látky. Aplikace pro vodárenské účely je modifikací této metody (detaily jsou predmětem probíhající patentové ochrany).

$\checkmark$ rámci řešení projektu Čistá voda - zdravé město proběhla modifikace metody CDC pro polární pesticidní látky. Aplikace pro regeneraci GAU vychází z predpokladu, že skelety nepolárních látek, na kterých byla technologie odzkoušena, jsou stabilnější než skelety námi požadovaných látek polárních. $\checkmark$ provedených modelových testech se tento predpoklad potvrdil, bylo dosaženo vysoké desorpční účinnosti. Významným faktorem pro určení účinnosti je řízení přenosu fáze, která je základem pro nasazení technologie $v$ prípadě vysokých objemů.

Výsledky experimentů ukazují, že tato metoda je dobře aplikovatelná pro rozličné druhy materiálů [17], a to jak v matricích pevných, tak i kapalných a plynných. S ohledem na relativně velké objemy materiálu při regeneraci GAU Ize použít dva možné postupy:

— regenerace, spojená s izolací vybraných látek do vhodné fáze, s následným nevratným odstraněním nežádoucích látek a jejich intermediátů,

- prímá regenerace na pevné fázi.

To, která cesta se použije, je zejména závislé na zachycovaných látkách, použitému sorpčnímu materiálu a požadované kapacitě metody.

Obdobná technologie s dostatečnou účinností v mobilním uspořádání není zatím na trhu dostupná. Naše technologie byla v předchozích generacích nasazena při pilotních sanačních pracích na kontaminovaném území skládky Organika Azot $v$ Jaworznu (Polsko) s detoxifikací koncentrovaných materiálů vybraných nepolárních organických látek [18] s výbornými výsledky. Přednosti metody CDC proti potenciálním konkurenčním technologiím jsou:

- vysoká destrukční účinnost,

— možnost mobilního nasazení (in-situ), malý záběr plochy,

- široký rozsah kontaminantů - destrukce nezávisí na stupni chlorace,

- likvidace terminálních látek i prekurzorů,

- plně nespalovací metoda, se zcela uzavřeným cyklem záchytu (bez úniků residuí do ovzduší),

- bez použití agresivních médií,

- jednoduchost - reakční mechanismus dobře popsaný, možnost optimalizace metody např. volbou množství katalyzátoru,

— schopnost kontroly všech látkových toků procesu,

- schopnost znovuzpracovat materiály je-li potřeba proces opakovat kvůli dosažení maximální možné účinnosti,

— spolehlivost - pro širokou škálu koncentrací od stopových množství až po koncentráty kontaminantů,

- nenáročnost obsluhy.
Technologickou modifikaci pro účelné, ekonomické recyklace sorpční náplně GAU je možné chápat jako analogii technologie CDC, jejíž zjednodušené vývojové schéma je na obr. 3 .

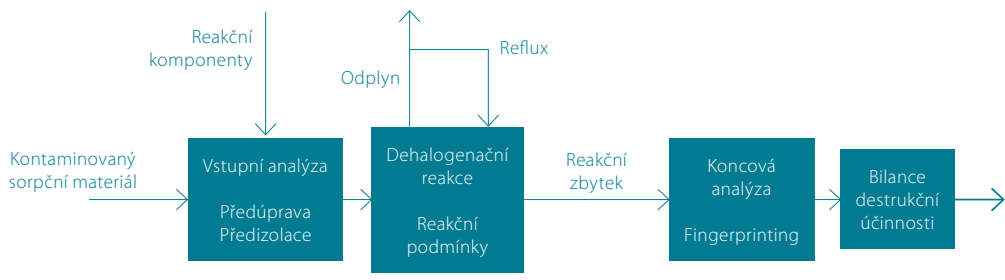

Obr. 3. Diagram procesu regenerace

Fig. 3. Regeneration process diagram

Některé parametry technologie CDC:

— reaktorem je tlaková nádoba s mícháním, s prívodem nosného plynu, chlazením odplynu, s děličem frakce (reflux) a elektrickým ohřevem,

— približný gradient ohřevu: cca $300^{\circ} \mathrm{C} / 45$ minut,

— teplotní profil řizených reakcí: $100-300^{\circ} \mathrm{C}$,

- reakčními komponentami je modifikovaný směsný katalyzátor,

- doba reakce: 4 až 8 hodin,

- chlazení vsázky: volné,

- objem reaktoru v mobilním uspořádání: 0,2-5 m³,

— reprezentativní velikost vzorků každé vsázky: cca 250-1000kg,

- analytické stanovení destrukční účinnosti.

\section{Princip metody CDC}

V reaktoru probíhá katalytická reakce halogenových organických sloučenin za prítomnosti mědi a donoru vodíku nezávisle na stupni halogenace a pozici halogenu u těchto sloučenin. Nejedná se o spalovací technologii, což je její velkou výhodou. Katalytický mechanismus je podrobně publikován v [16]. Jeho vhodnou modifikací a užitým katalyzátorem je možné rozširíit využití CDC na širší skupinu látek, které jsou více polární a/nebo nemají ve svém skeletu halogen.

Při dehalogenaci se pak uplatňuje následující patentovaný reakční mechanismus (1):

$$
[\mathrm{ArCu}]+\mathrm{H}^{+} \longrightarrow \mathrm{ArH}+\mathrm{Cu}^{+}
$$

a k Ullmanově reakci (biarylová tvorba) za vzniku netoxických a dále využitelných látek $(2,3)$ :

$$
\begin{aligned}
& 2[\mathrm{ArCu}] \longrightarrow \mathrm{Ar}-\mathrm{Ar}+2 \mathrm{Cu}^{0} \\
& {[\mathrm{ArCu}]+\mathrm{ArX} \longrightarrow \mathrm{Ar}-\mathrm{Ar}+\mathrm{CuX}}
\end{aligned}
$$

V případě i termodynamicky méně stabilních skeletů, než jsou Ar-Ar pak dochází k jejich nevratnému rozpadu na netoxické fragmenty, přičemž halogeny precházejí do anorganické formy soli nebo slabé kyseliny, jež se zachytávají v mokré pračce. Celkový proces je uzavřen, ke zbytkovým únikům zbytkových látek (např. do ovzduší) tak nedochází. 
Pro regeneraci aktivního uhlí mohou testy probíhat ve dvou uspořádáních:

1. laboratorní modelový testovací reaktor pro malé objemy simulující podmínky v provozním reaktoru,

2. provozní reaktor.

\section{Mobilní uspořádání}

Jednotka CDC tak, jak je v současné době provozovaná, má možnost stacionárního i mobilního uspořádání. Mobilní jednotka je přenositelná na místo realizace, namísto logisticky komplikované přepravy materiálu. Na obr. 4 je ukázána současná verze mobilní jednotky. Všechny konstrukční prvky CDC jednotky jsou umístěny do robustního technologického rámu. Pro mobilní uspořádání je rám navržen tak, aby odpovídal umístění v technologickém kontejneru ISO. Proces je rízen centrální rídící jednotkou podle různých, předem stanovených destrukčních programů. Sledování destrukční účinnosti se provádí analýzou odebraných vzorků během a po procesu destrukce ze vzorkovacích míst ze dna reaktoru.

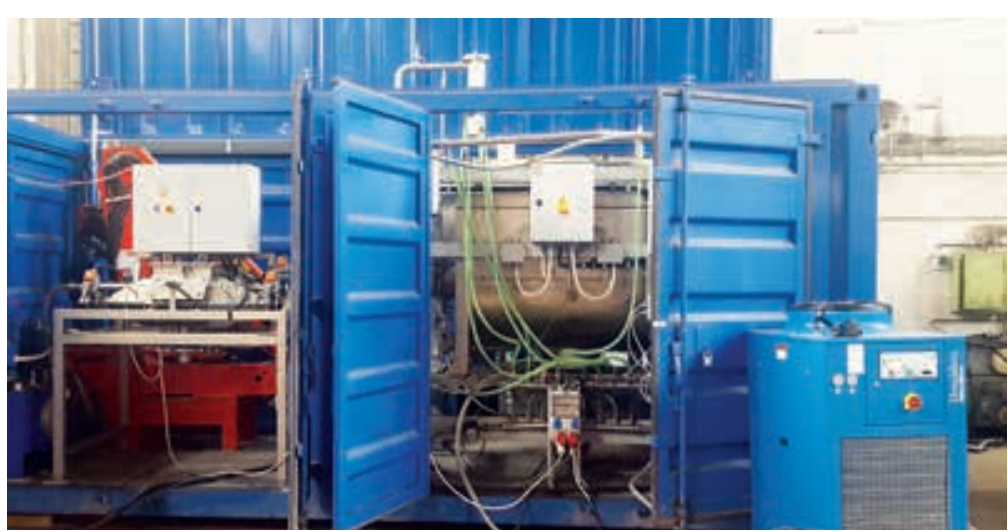

Obr. 4. Mobilní technologie CDC

Fig. 4. CDC mobile technology

\section{Modelové laboratorní uspořádání}

V rámci řešení projektu Čistá voda - zdravé město byly destrukční testy realizovány v laboratorním uspořádání. V laboratorním reaktoru byly vyhodnocovány poměry vstupních reakčních komponent, jejich vhodnost a vliv matrice a druhu vstupního kontaminovaného materiálu. Jako reaktor byl použit autokláv s těmito parametry:

— reakční teplota: $100-300{ }^{\circ} \mathrm{C}$ sledována teplotním čidlem s automatickým záznamem (viz obr. 5),

- objem nerezové reaktorové nádoby: $400 \mathrm{ml}$,

— reakční doba: 4-8 hodin,

- prostředí: inertní atmosféra zamezující prístupu kyslíku je dosažena naplněním volného místa v reaktorové nádobě dusíkem před započetím zahřívání (přítomnost kyslíku by vedla k reakcím, kdy by vznikaly toxikologicky nebezpečnější sloučeniny nežli ty destruované),

- proces probíhal za stálého míchání, odběr vzorků po ukončení procesu (zchladnutí materiálu),

— ke zkoumanému vzorku byly přidány příslušné reakční komponenty (složení vsázky a modifikovaný katalyzátor); poměr jednotlivých komponent závisí na druhu a miře kontaminace vzorku pesticidními látkami.
Teplotní krivka v laboratorním reaktoru (ukázka prodlouženého 8hodinového cyklu)

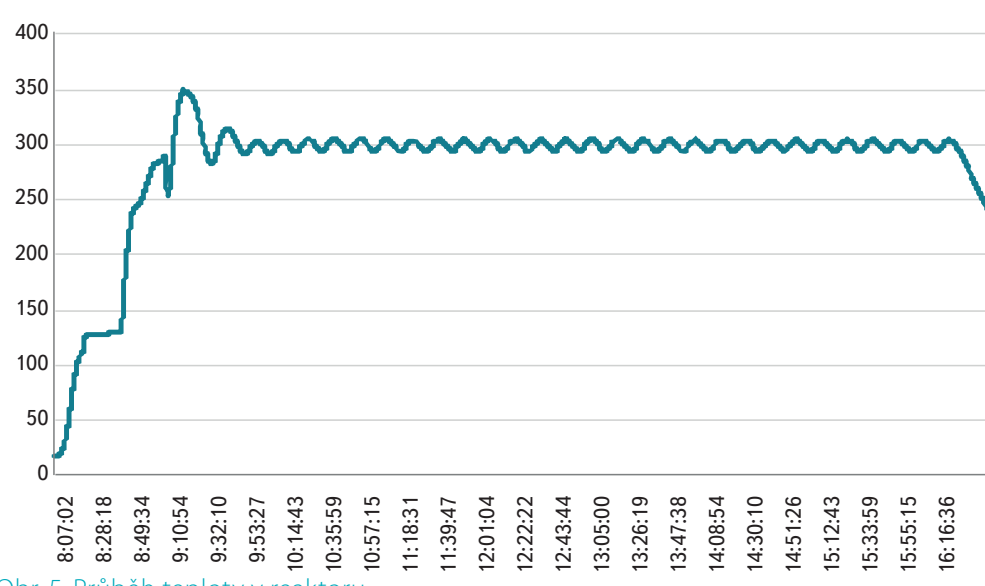

Obr. 5. Průběh teploty $\vee$ reaktoru

Fig. 5. Example of temperature course in reactor

\section{Modelové testy}

Při počátečních testech desorpce nasorbovaných organických látek katalytickou destrukcí na sorpční náplni GAU1 byly optimalizovány některé parametry metody, zejména hmotnost látek v reaktoru a doba výhřevu. Vyhodnocovanou veličinou byla destrukční účinnost v procentech, která je vypočtena jako poměr odezvy daného analytu (analytické plochy pod píkem) pro daný kontaminant před destrukcí (vstupní vzorek) ku vzorku výstupnímu po destrukci. Pro optimalizační testy byly použity vzorky obohacené předem definovanými koncentracemi vybraných pesticidů (účinných látek) obsažených v komerčních aplikačních prípravcích.

Optimalizované parametry destrukce CDC metodou pro porovnávací testy pro GAU1 až GAU5 byly následující:

- doba vyhřívání: 4 hodiny,

- hmotnost katalyzátoru: méně než $1 \%$,

— hmotnost donoru vodíku: méně než $1 \%$.

Pro porovnávací desorpční testy byly využity reálné vzorky nasorbovaných GAU z kolonových sorpčních testů.

\section{VÝSLEDKY A DISKUSE}

\section{Modelové testy sorpce}

Sorpční účinnost v procentech byla vypočtena jako poměr odezvy (plochy píku daného analytu) vzorku vody (filtrátu) po všech realizovaných filtračních cyklech a vzorku vstupního (počátečního) roztoku před započetím sorpčního testu. V tabulce 4, která uvádí srovnání sorpční účinnosti jednotlivých GAU1 až GAU5, jsou uvedeny sorpční účinnosti pro jednotlivé účinné látky po 4. (závěrečném) filtračním cyklu. Během experimentů byly tyto účinnosti zkoumány vždy po každé filtraci (F1-F4), což poskytuje informaci o míre úbytku dané látky v každém filtračním cyklu (viz obr. 6-10).

Uspořádání experimentu sorpčních kolonových testů se ukázalo jako vhodné pro stanovení sorpční účinnosti GAU. Z výsledků vyplývá velmi vysoká sorpční účinnost u všech zkoumaných typů GAU pro většinu zkoumaných polárních látek. Nejnižší účinnost sorpce byla prokázána $\vee$ prípadě GAU4, což je s velkou pravděpodobností dáno velikostí částic tohoto sorbentu. 
Tabulka 4. Porovnání záchytu pro jednotlivé druhy uhlípo 4. filtračním cyklu Table 4. Sorption efficiency comparison after $4^{\text {th }}$ filter cycles for five different GAUS

Polární látka Sorpční účinnost [\%]

\begin{tabular}{llllll}
\hline & GAU1 & GAU2 & GAU3 & GAU4 & GAU5 \\
\hline Linuron & 99,81 & 99,73 & 99,83 & 98,81 & 99,83 \\
\hline Terbuthylazin & 99,74 & 99,07 & 99,55 & 98,12 & 99,98 \\
\hline Metazachlor & 99,83 & 99,90 & 99,91 & 97,27 & 99,89 \\
\hline DEET & 99,46 & 99,44 & 99,93 & 97,75 & 99,68 \\
\hline Benzotriazol & 99,50 & 99,68 & 99,58 & 97,83 & 99,99 \\
\hline Chloridazon & 99,72 & 99,81 & 99,78 & 99,36 & 99,73 \\
\hline Propamocarb & 99,18 & 99,81 & 99,96 & 97,03 & 99,49 \\
\hline Pirimicarb & 99,75 & 99,83 & 99,89 & 98,34 & 99,99 \\
\hline Azoxystrobin & 99,82 & 99,56 & 99,83 & 97,57 & 99,93 \\
\hline Aclonifen & 99,94 & 99,19 & 99,90 & 99,01 & 99,97 \\
\hline MCPA & 99,25 & 99,91 & 99,98 & 98,49 & 99,97 \\
\hline Difenoconazol & 99,90 & 99,17 & 99,74 & 97,76 & 99,77 \\
\hline Glyfosát & 80,98 & 86,04 & 98,63 & 50,31 & 93,97 \\
\hline Clomazon & 73,55 & 90,36 & 95,93 & 95,42 & 99,74 \\
\hline Fluroxypyr & 97,99 & 95,06 & 99,20 & 88,03 & 98,81 \\
\hline
\end{tabular}

Účinnost sorpce po 1. až 4. filtraci na GAU1 v \%

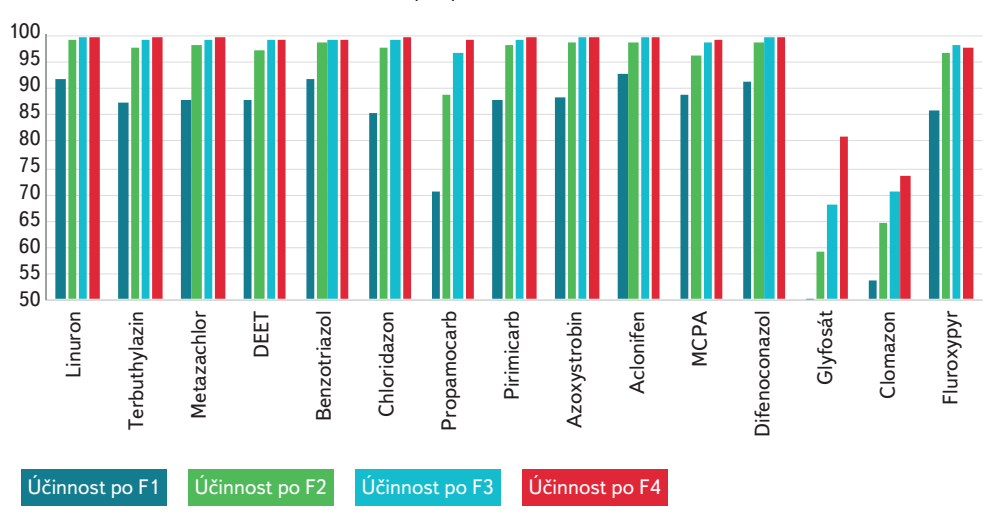

Obr. 6. Účinnost sorpce pro GAU1

Fig. 6. Sorption efficiency for GAU1

Jeho specifický povrch $v \mathrm{~m}^{2} \cdot \mathrm{g}^{-1}$ je sice mezi testovanými GAU nejvyšší, ale jeho využitelnost ve vnitřnějších partiích částic pro sorpci vyžaduje patrně větší čas, než který byl k dispozici v provedeném experimentu. Přícinou mohou být i stereochemické aspekty. Vyšší pozornost je potřeba věnovat posledním třem látkám ze seznamu testovaných látek: glyfosátu, clomazonu, fluroxypyru, jejichž sorpční účinnost byla zjištěna nejnižší. Sorpční účinnost glyfosátu může být ovlivněna jeho vysokou polaritou. U fluroxypyru ( $v$ prípravku Bofix) máme podežrení na jeho nesnadnou rozpustitelnost ve vodě, výsledek může být

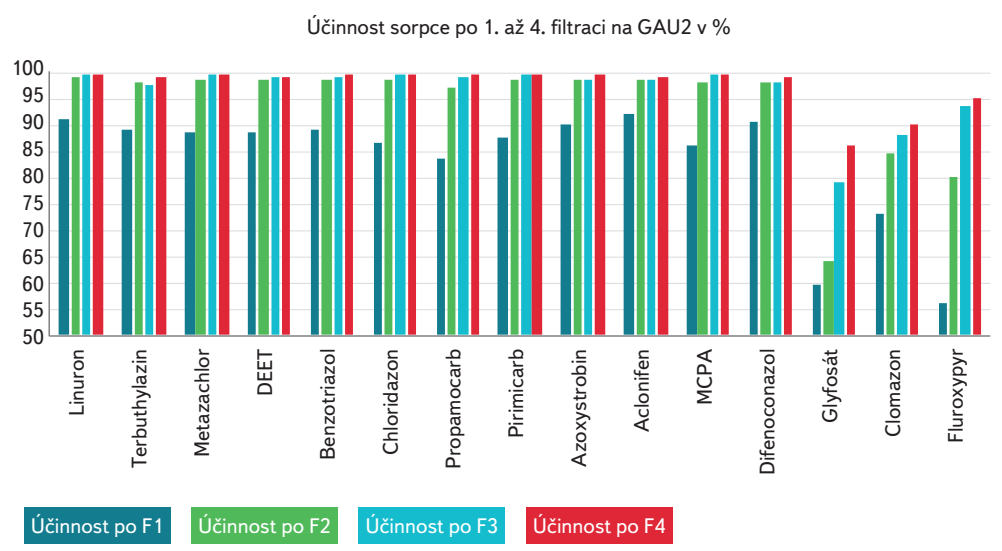

Obr. 7. Účinnost sorpce pro GAU2

Fig. 7. Sorption efficiency for GAU2

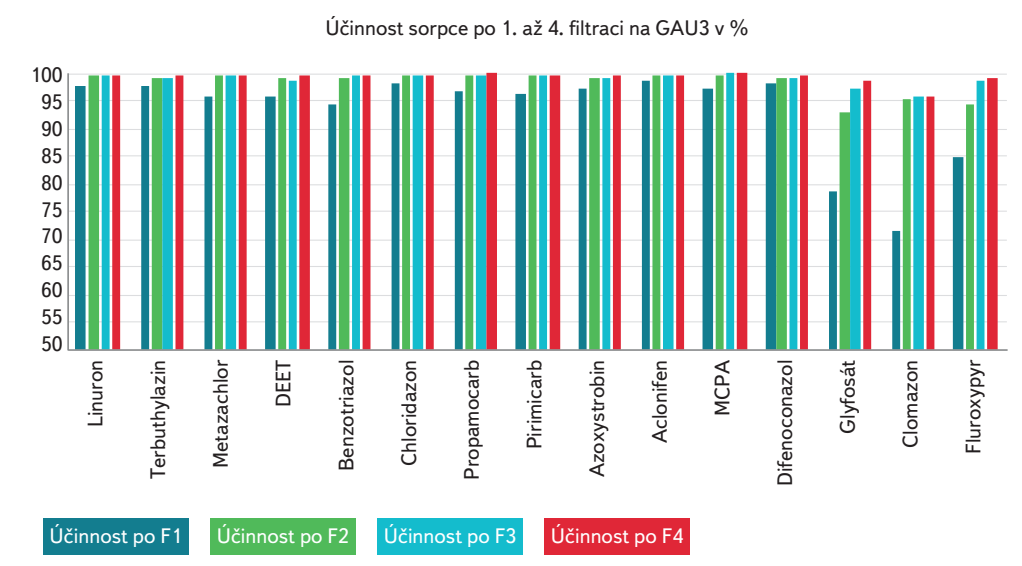

Obr. 8. Účinnost sorpce pro GAU3

Fig. 8. Sorption efficiency for GAU3

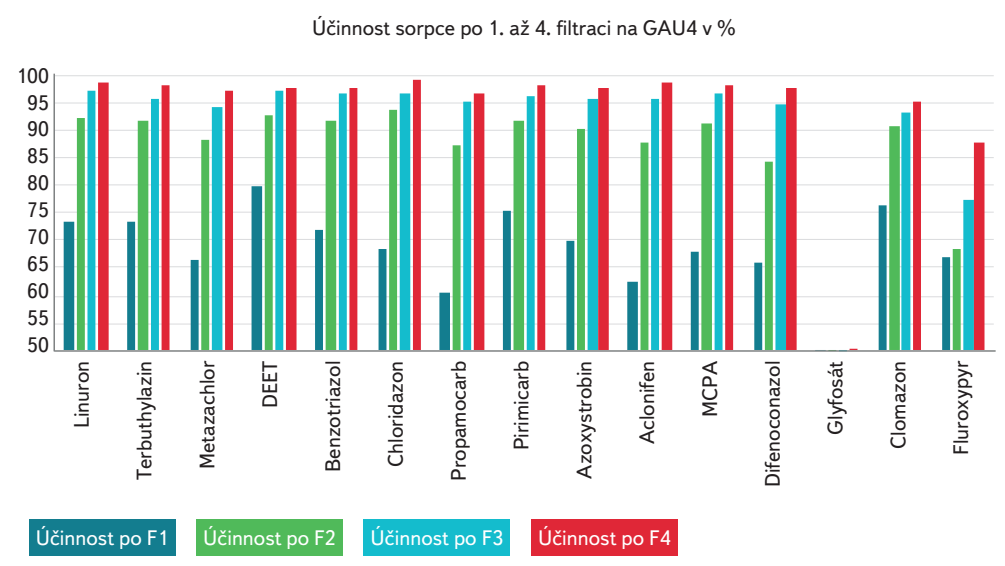

Obr. 9. Účinnost sorpce pro GAU4

Fig. 9. Sorption efficiency for GAU4

ovlivněn jeho koncentrační nehomogenitou ve vodném prostředí. Výsledné účinnosti sorpce jsou vztažené k dané vstupní koncentraci sledovaných látek, závislost účinnosti na stupni kontaminace ovlivňuje i sorpční kapacita daného GAU. Pro odhad této kapacity je vhodný napríklad vsádkový-míchaný laboratorní test. 
Účinnost sorpce po 1. až 4. filtraci na GAU5 v \%

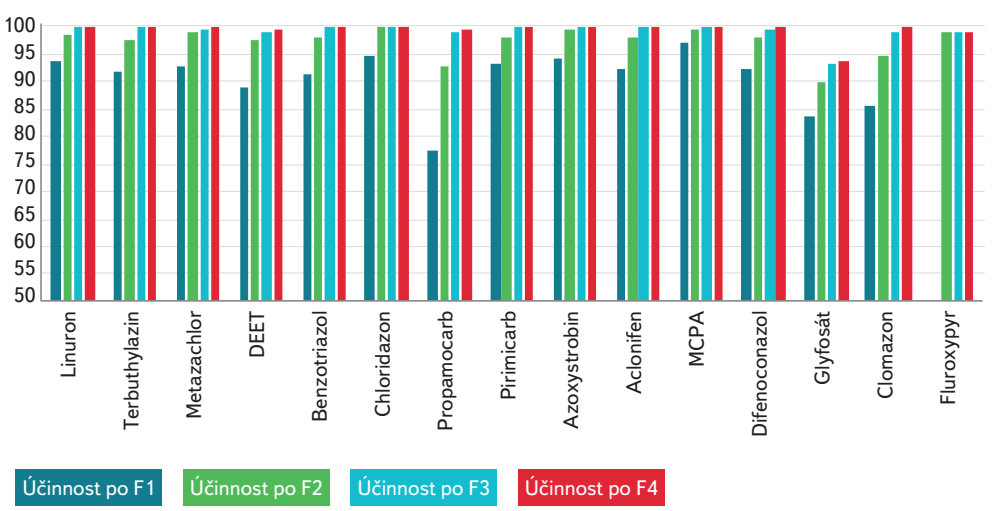

Obr. 10. Účinnost sorpce pro GAU5

Fig. 10. Sorption efficiency for GAU5

\section{Modelové testy desorpce}

Výsledky modelových testů desorpce reálných vzorků katalytickou destrukcí $\checkmark$ laboratorním reaktoru jsou uvedeny $v$ tabulce 5. Experimenty byly provedeny pro dvě různé vstupní koncentrace rostlinolékařských prípravků získaných z kolonových sorpčních testů. Koncentrační úrovně (dané odezvou signálu chromatografické analýzy) se pro jednotlivé analyty pohybovaly v rozsahu až pěti rádů. V tabulce 5 nejsou uvedeny zkoumané pesticidní látky glyfosát, fluroxypyr a chloridazon, u kterých byly počáteční koncentrace před provedením testů blízké limitům detekce analytického systému LC-MS.

Byla ověřena vysoká destrukční účinnost testovaných organických látek u všech typů GAU. Desorpční účinnost dosahovala v mnohých případech hodnot kolem 99 \%. Rozdíly destrukční účinnosti mezi testem č. 1 a testem č. 2
Účinnost destrukce látek exponovaných sorpčních náplní CDC metodou v \%

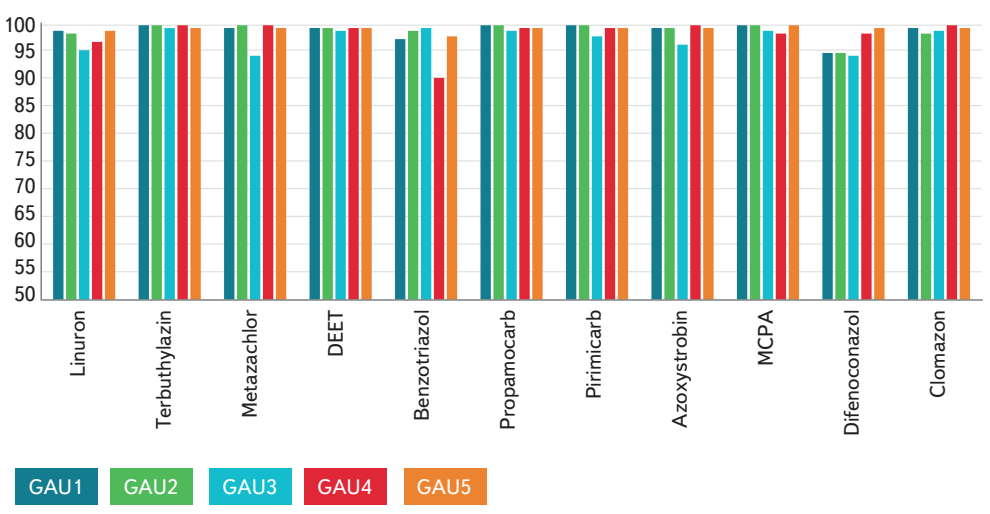

Obr. 11. Účinnost destrukce organických látek exponovaných sorpčních náplní CDC metodou

Fig. 11. Destruction efficiency of the exposed GAC by CDC method

Ize vysvětlit odlišnou vstupní koncentrací analytů před desorpcí. Nejnižší hodnoty destrukční účinnosti 80 až 90 \% byly zjištěny vždy pouze u testu č. 2 v př́padě účinných látek, které měly relativně nízkou počáteční koncentraci (před provedením testu) blízkou limitům detekce. Nižší destrukční účinnosti byly zjištěny také v testu č. 2 pro GAU4, jehož zpracování je provedeno ve formě peletek. Obecně vyšších destrukčních účinností bylo dosaženo u testů č. 1, kde byly vyšší počáteční koncentrace zkoumaných látek. Modelové experimenty prokázaly schopnost CDC katalytické metody destruovat zájmové polární látky z kontaminovaných vzorků u všech GAU s vysokou účinností (obr. 11).

Tabulka 5. Destrukčni účinnost pro jednotlivé druhy GAU Table 5. Destruction efficiency for five GAUs

Polární látka

GAU1
GAU2
GAU3

GAU4

GAU5

\begin{tabular}{|c|c|c|c|c|c|c|c|c|c|c|}
\hline & \multicolumn{10}{|c|}{ Destrukční účinnost [\%] } \\
\hline & Test 1 & Test 2 & Test 1 & Test 2 & Test 1 & Test 2 & Test 1 & Test 2 & Test 1 & Test 2 \\
\hline Linuron & 98,83 & 97,65 & 98,69 & 99,60 & 95,41 & 93,42 & 97,18 & 93,49 & 99,14 & 94,43 \\
\hline Terbuthylazin & 99,81 & 99,44 & 99,77 & 99,12 & 99,57 & 92,79 & 99,81 & 95,94 & 99,67 & 99,87 \\
\hline Metazachlor & 99,58 & 99,36 & 99,76 & 98,36 & 94,47 & 87,92 & 99,81 & 96,87 & 99,64 & 99,84 \\
\hline DEET & 99,64 & 99,29 & 99,67 & 99,00 & 99,21 & 91,40 & 99,62 & 92,63 & 99,50 & 99,52 \\
\hline Benzotriazol & 97,29 & 98,18 & 98,94 & 99,13 & 99,68 & 90,57 & 90,57 & 92,11 & 97,81 & 97,89 \\
\hline Propamocarb & 99,82 & 99,65 & 99,87 & 93,82 & 98,84 & 86,70 & 99,72 & 86,17 & 99,69 & 99,51 \\
\hline Pirimicarb & 99,76 & 99,54 & 99,87 & 98,97 & 97,95 & 92,28 & 99,75 & 93,38 & 99,65 & 99,57 \\
\hline Azoxystrobin & 99,39 & 99,61 & 99,56 & 99,01 & 96,53 & 90,00 & 99,83 & 93,31 & 99,63 & 92,72 \\
\hline MCPA & 99,93 & 99,87 & 99,91 & 98,87 & 99,18 & 94,29 & 98,43 & 96,10 & 99,76 & 98,29 \\
\hline Difenoconazol & 94,86 & 98,31 & 95,04 & 97,67 & 94,45 & 89,18 & 98,57 & 91,97 & 99,46 & 99,55 \\
\hline Clomazon & 99,31 & 98,53 & 98,72 & 99,32 & 99,06 & 83,16 & 99,87 & 95,48 & 99,64 & 99,34 \\
\hline
\end{tabular}




\section{ZÁVĚR}

Provedenými testy na vybraných pěti typech sorpčních náplní na bázi aktivního uhlí byla zjištěna vysoká účinnost sorpce a následná desorpce většiny účinných látek rostlinolékařských prípravků a dalších organických látek CDC metodou. Nižší účinnosti sorpce a desorpce byly ověřeny v prípadě sorpční náplně NORIT® GAC 1020 EN (GAU4), která je dána tvarovou a velikostní odlišností oproti ostatním typům granulovaného aktivního uhlí. V prípadě glyfosátu, clomazonu a fluroxypyru byla zjištěna nižší sorpční účinnost v prvním a druhém filtračním cyklu u všech typů testovaných GAU, ve třetím a čtvrtém cyklu však byla účinnost sorpce u testovaných GAU3 (NORIT GAC 1240 W) a GAU5 (AquaSorb 6300) srovnatelná s ostatními testovanými organickými látkami. Tyto dva poslední jmenované druhy sorpčních náplní se také potvrdily jako nejúčinnější pro sorpci studovaných polárních organických látek. Nejvyšší účinnosti destrukce exponovaných sorpčních náplní CDC metodou bylo dosaženo v prípadě sorbentů GAU5 (AquaSorb 6300), GAU1 (Chemviron Filtrasorb TL830) a GAU2 (Chemviron Filtrasorb 400).

\section{Poděkování}

Př́spěvek byl zpracován v rámci projektu "Čistá voda-zdravé mèsto: Cizorodé látky ve vodách podzemních, povrchových a odpadnich" (registrační čislo projektu CZ.07.1.02) 0.0/0.0/16_040/0000378), Koncept I "Studie vnosu pesticidù do vodárenské nádrže Švihov (Želivka) s využitím nových vzorkovacích technik a odstranění organických látek ze sorpčních filtrů za ozonizací vysoce-účinnou chemickou destrukci".

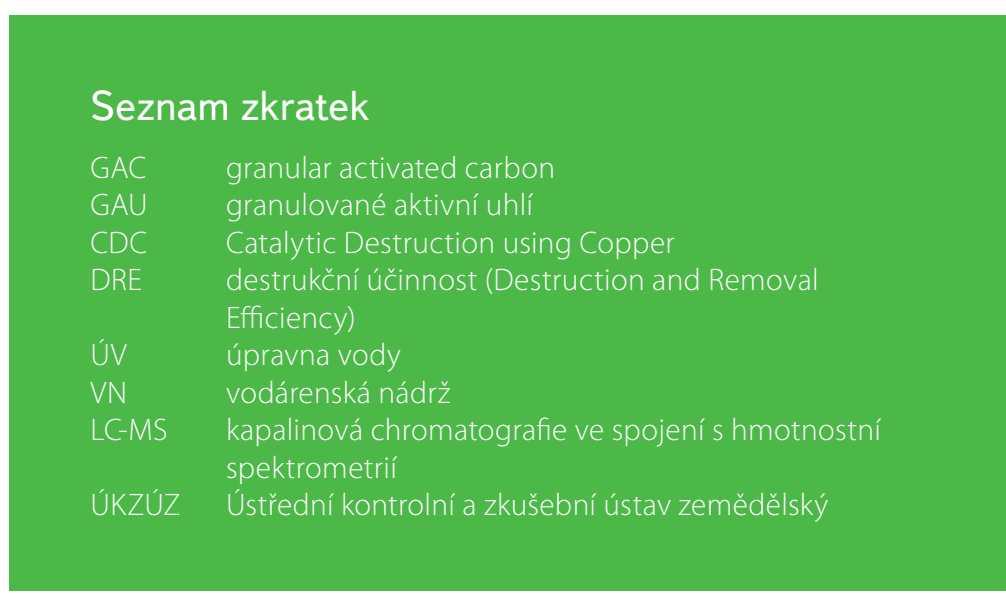

\section{Literatura}

[1] LIŠKA, M. a kol. Problematika výskytu pesticidních látek v povrchových vodách v povodí vybraných vodárenských zdrojů. Vodní hospodárství, 2015, č. 1, s. 14.

[2] LIŠKA, M., SOUKUPOVÁ, K., DOBIÁŠ, J., METELKOVÁ, A., GOLDBACH, J. a KVÍTEK, T. Jakost vody ve vodárenské nádrži Švihov na Želivce a jejím povodí se zaměřením na specifické organické látky. Vodohospodářské technicko-ekonomické informace, 2016, roč. 58, č. 3, s. 4-11. ISSN 0322-8916.

[3] Online, staženo 15. 12. 2019. Dostupné z: https://heis.vuv.cz/data/webmap/datovesady/projekty/ polrustu2cistavoda

[4] TUŠIL, P. SWOT analýza modernizace úpravny vody Želivka. Vodohospodářskétechnicko-ekonomické informace, 2016, roč. 58, č. 2, s. 28-37. ISSN 0322-8916

[5] PINKER, B. Význam reaktivace granulovaného aktivního uhlí používaného pro úpravu pitné vody. Vodní hospodáŕství, 1997, roč. 47, č. 5, s. 166-168.

[6] KOPECKÝ, J. Aktivní uhlí - technologie pro úpravu pitných a bazénových vod. Vodní hospodářství, 2003, roč. 53, č. 7, s. $185-187$

[7] MOHAN, D. and SINGH, K.P. Granular activated carbon. Domestic, municipal, and industrial water supply and waste disposal. Published by John Wiley \& Sons. Water Encyclopedia, 2005, Vol. 1, p. 92-107.

[8] DUC, L.D. Studium adsorpce přirozených organických látek na aktivním uhlí při úpravě pitné vody. Diplomová práce VUT, Brno, 2008.
[9] KOPECKÁ | Adsorpce pesticidů na granulovaném aktivním uhlí při úpravě vody. Diplomová práce, Ústav pro životní prostředí, PF UK, Praha, 2010

[10] DĄBEK, L. Sorption of zinc from aqueous solutions on regenerated activated carbons. Journal of Hazardous Materials, 2003, p. 191-201.

[11] DOBIÁŠ, J., KOŽELUH, M., ZAJIČEK, A., FUČÍK, P. a LIŠKA, M. Dynamika vyplavování pesticidních látek v povodí Čechtického potoka. Vodohospodářské technicko-ekonomické informace, 2018, roč. 60, č. 4, s. 10-16. ISSN 0322-8916.

[12] General technical guidelines on the environmentally sound management of wastes consisting of, containing or contaminated with persistent organic pollutants. UNEP/CHW.13/6/Add.1, 2018

[13] PEKÁREK, V., OCELKA, T., GRABIC, R., and BUREŠ, M. The Application of Copper Mediated Destruction Method (CMD) for Destruction of Clorinated Pesticides and some Pre-dioxin and POP Compounds. $8^{\text {th }}$ International HCH and Pesticides Forum, Bulgaria, 2005.

[14] OCELKA, T. and PEKÁREK, V. Copper Mediated Destruction: novel method for destruction of chlorinated pesticides and other halogenated POPs. 10 $0^{\text {th }}$ HCH FORUM, IHPA, Brno, 2009

[15] OCELKA, T., PEKÁREK, V., FIŠEROVÁ, E., ABBRENT, M., KOHUTOVÁ, J., HETFLEJŠ, J., and LOJKÁSEK, M. Copper mediated destruction (CMD) - a novel BAT technology for POPs destruction. Organohalog Compd., 2010, 72, p. 1258-1259.

[16] PEKÁREK, V., HAPALA, P., and FIŠEROVÁ, E. Process for Dehalogenative Detoxification of Halogen Aromatic and/or Cyclic Compounds. EU Patent application No.PCT/CZ2004/000024.

[17] ISHIDA, M., SHIJI, R., NIE, P., NAKAMURA, N., and SAKAI, S. Full-scale plant study on low temperature thermal dechlorination of PCDDs/PCDFs in fly ash. Chemosphere, 1998, Oct-Nov, 37, p. 9-12. ISSN 2299-308

[18] OCELKA, T., NIKL, S., KURKOVA, R., and PAVLISKA, L. Application of Copper Mediated Destruction technology for trial dehalogenation of pesticides concentrates in Jaworzno dump site in mobile ful scale unit. $17^{\text {th }}$ HCH and Pesticides Forum, Azerbaijan, 2011

\section{Autoři}

Ing. Tomáš Mičaník, Ph.D. ${ }^{1}$

凶tomas.micanik@vuv.cz

\section{Ing. Jiří Oceánský}

凶jiri.oceansky@ehss.eu

Mgr. Jiří Lisník ${ }^{2}$

凶jiri.lisnik@ehss.eu

Ing. Tomáš Ocelka, Ph.D. ${ }^{2}$

凶tomas.ocelka@ehss.eu

'Výzkumný ústav vodohospodářský T. G. Masaryka, v. v. i., pobočka Ostrava ${ }^{2}$ E\&H services, a. $\mathrm{s}$.

Príspěvek prošel lektorským řizením. 
TEST OF SORPTION FILTERS ON THE BASE

OF GRANULAR ACTIVATED CARBON

FOR DRINKING WATER CLEANING

\section{MICANIK, T.'; OCEANSKY, J. ${ }^{2}$; LISNIK, J.²; OCELKA, T. ${ }^{2}$}

'TGM Water Research Institute, p.r.i., Ostrava Branch

${ }^{2} \mathrm{E} \& \mathrm{H}$ services, a. $\mathrm{s}$.

Keywords: sorption - desorption - catalytic destruction using copper - dehalogenation technology - GAC filtration pesticides - water reservoir Švihov - sorbent regeneration

The contribution presents model tests of sorption efficiency and elimination of organic substances, especially pesticides from five different exposed granular activated carbon (GAC). Results can contribute to the understanding of suitable filter lines for the realized investment project GAC filtration. It provides the purification of treated water at the Želivka Drinking Water Treatment Plant. There were realised sorption efficiency tests in a column arrangement for selected 15 polar substances. The presence of this substances was proven in the Želivka river basin and in the Švihov water reservoir. High sorption efficiency was reached exceeding 99\% was found in our tests for most of the test substances. Part of the project was to verify the possibility of using the technology of catalytic destruction of CDC (Catalytic Destruction using Copper) for GAC regeneration (reactivation). Destructive efficiency (as DRE) of CDC technologies was investigated in a laboratory reactor, for most substances high elimination values above $99 \%$ were achieved. 